\title{
Inquiring into the political economy of oil palm as a global flex crop
}

\author{
Alberto Alonso-Fradejas, Juan Liu, Tania Salerno and Yunan Xu
}

\begin{abstract}
Oil palm production, consumption, and the trade of its multiple commodities have expanded exponentially in recent decades. This paper argues that this expansion will continue due to, and along with it, the rise of 'flexing' among its increasing multiple uses, especially for more industrial and energy purposes. Oil palm has been extensively analysed in the context of land grabs and agrarian change, land conversion and deforestation. However, its nature as a flex-crop remains unexplored, especially with respects to the convergence of global food, fuel and environmental crises. This paper provides a preliminary discussion of how oil palm fits in the flex crop framework to analyse its enabling material and ideational bases, as well as who informs, decides, and controls the nature of flexing. This is done through an analysis of the different roles played by state, corporate (private) and social actors in the flexing of oil palm across the globe. We conclude by drawing some implications for further research.
\end{abstract}

Key words: oil palm; flex crops and commodities; value web; political economy of agriculture; BRICS and MIC countries.

\section{Introduction}

For thousands of years, oil palm (Elaeis guineensis) has been used, processed and extracted for various purposes. Today it is a globally traded commodity with extensive uses, including both food and nonfood purposes. This paper argues that, the renewed interest in oil palm is based on its increasing value as a 'flex-crop', rooted in the converging world food, fuel, financial and environmental crises, and the transition towards 'a multi-centric global food system' (McMichael 2012, 684).

Flex crops and commodities are defined by Borras et al. as those with 'multiple uses (food, feed, fuel, industrial material) that can be, or are thought to be, flexibly inter-changed' $(2014,1)$. This concept can be traced back to that of 'substitutionism' in the bio-industrialization of agricultural commodities, put forward by Goodman, Sorj and Wilkinson in 1987; as they examined how 'the new biotechnologies will enhance the efficiency with which all forms of biomass, whether field crops, crop residues, wood or organic waste, are converted in all uses, not only into food products but also fuel and chemical' (Goodman et al. 1987, 136 stress in original). They argued that biotechnologies, allowing for improved conversion/processing and fractionation of raw materials through industrial microbiology, would 'transform [the agricultural] product, whether food or non-food, into basic 
chemical constituents or intermediates with multiple competing uses' (Goodman et al. 1987, 141). This idea of substitutionism links to the multiple uses of a crop. Rexen and Munck take the argument further and propose the logic of flexing among multiple uses; as they argue, 'all the constituents are used as optimally as possible. Nothing is wasted...The proportions between the different streams can easily be changed according to actual demand and price relationships in the market' (1984 in Goodman et al. 1987, 182, emphasis added). Therefore, the value of flex crops is related to the versatility of its derived commodities in volatile markets. As Borras et al. explain, 'flex crops seem to reduce uncertainty in a single crop sector through diversification of the product portfolio, thereby enabling investors to better anticipate and more nimbly react to changing prices in either direction e.g., to better exploit price spikes or to better withstand price shocks' (2014, 2). Indeed, agroindustrial flex crops could be understood, in a way, as the corporate form of millenary peasant multicropping farming. Of course, there are major differences, not least the fact that in the case of the peasantry multi-cropping is used as a form of risk management for reproductive purposes and livelihood protection, while in the case of the contemporary form of financialised agribusinesses this is a risk management tool for further control and capitalization on the agricultural system.

To understand how investors may use flex crops to control risk and uncertainty, it is useful to analyse the flexing among multiple uses of oil palm within a 'value web' (Borras et al. 2014), rather than alongside a value "chain". This approach is more relevant to the analysis of oil palm flexing as it makes way for the complexity of actors, processes, structures, and their interrelations, in and around oil palm flexing ${ }^{1}$. As argued by Virchow et al.:

'We develop a biomass-based value web approach, in which the 'web perspective' is used as a multi-dimensional methodology to understand the interrelation between several value chains, to explore synergies and to identify inefficiencies in the entire biomass sector [..] The web perspective focuses on the numerous alternative uses of raw products, including recycling processes and the cascading effects during the processing phase of the biomass utilization' (2014, n.p.).

While oil palm is a very contentious crop which has been at the centre of much discussion regarding the economic and socio-ecological impacts of land conversion, forest destruction, and financialization, discussions on oil palm flexing remain at the 'anecdotal faze'. Borras et al. explain the need to expand the discussion and approach to critical questions on flexing in general in the following terms:

To what extent this actually occurs, how this actually happens and what factors encourage/discourage, facilitate or block real flexing from happening in one sector vs. another, or from one geographic setting to the next, are all empirical questions that ought to be investigated more carefully—and urgently $(2014,8)$.

\footnotetext{
${ }^{1}$ For a historical perspective on the development of the oil palm complex see chapter 1 in Corley and Tinker 2003.
} 
Since this is a relatively new avenue of analysis, the way oil palm as a flex crop is being used in response to crises, and more generally within the current world politico-economic conjuncture, cannot be fully examined here. The discussion will also not delve too extensively into the intricacies of the oil palm value web nor the changing dynamics between key actors, their relations, and the trends brought about through financialisation in particular - such as the increasing interconnection of agribusiness and other industrial and financial sectors. Instead, this paper is a preliminary investigation of the extent to which the oil palm sector fits in the flex crop framework proposed by Borras et al. (2014) and what are the implications of this from a critical (agrarian) political economy perspective. The aim, then, is to pose fundamental questions regarding oil palm flexing, including: what are oil palm's multiple uses today? And what is their relative importance?; who decides about the uses?; why and how does flexing actually happen?; what are the roles of different state, social and corporate actors in the flexing of oil palm?'; and how does this all fit into the wider trends of change in the dominant 'food regime' (Friedmann and McMichael 1989)?

This contribution will therefore ask more questions than propose answers, to contribute to the growing call for research in and around the flex crop and commodities phenomenon. This is done by first presenting the multiple uses and values of oil palm around two main streams; those related to palm oil and those associated with oil palm's biomass. Next, a discussion on oil palm's enhanced flexing possibilities is used to examine the why of oil palm flexing. Three major and interconnected drivers of oil palm flexing today are proposed: The first is that of the accumulation imperative, the second is related to the green economy paradigm, and the third is linked to changes towards a multipolar world food and agro-commodities regime. The subsequent section builds on this general framing of the drivers and looks towards the actors involved in shaping the flexing of oil pam, their rationales, aims, and the ways they relate to one another. A political economy lens is used to further explore the workings of oil palm flexing with an analysis of who informs, decides, and controls the nature of flexing. This is done through a general and preliminary analysis of the different roles played by state, corporate (private) and social actors in the flexing of oil palm. The concluding section suggests some implications for further research.

\section{The increasing multiple uses of oil palm}

According to the Technical Director of the Roundtable on Sustainable Palm Oil (RSPO), 'more than $50 \%$ of the products you find in a supermarket contain palm oil ${ }^{2}$. As it stands, palm oil is already used in various products and has become deeply integrated into our daily lives. It is not only in processed foods but is also used for fuel and beauty products. In other words, in an average day it is likely that a person uses it multiple times, making oil palm a "golden crop" for investors in the current agricultural system. The new uses currently developed for palm oil, together with those

2 In First Latin American Conference of Oil Palm Growers, Guatemala, October 172013 
related to oil palm's biomass will make oil palm an even more essential crop in the future. From a critical political economy perspective, the implications of the rise of oil palm are related to how the multiple uses and flexing possibilities of oil palm have transformed this agricultural crop into an avenue for investment and accumulation.

This "golden crop" has consequently expanded rapidly and substantially worldwide, and especially in in several so-called Middle-Income Countries (MICs), namely, Indonesia, Malaysia, Thailand, Cambodia, Colombia and Nigeria. Figure 1 outlines how much oil palm fruit is harvested in these key producing countries and in the world.

Figure 1: Harvest area of oil palm fruit in key producing countries and worldwide (1000 ha)

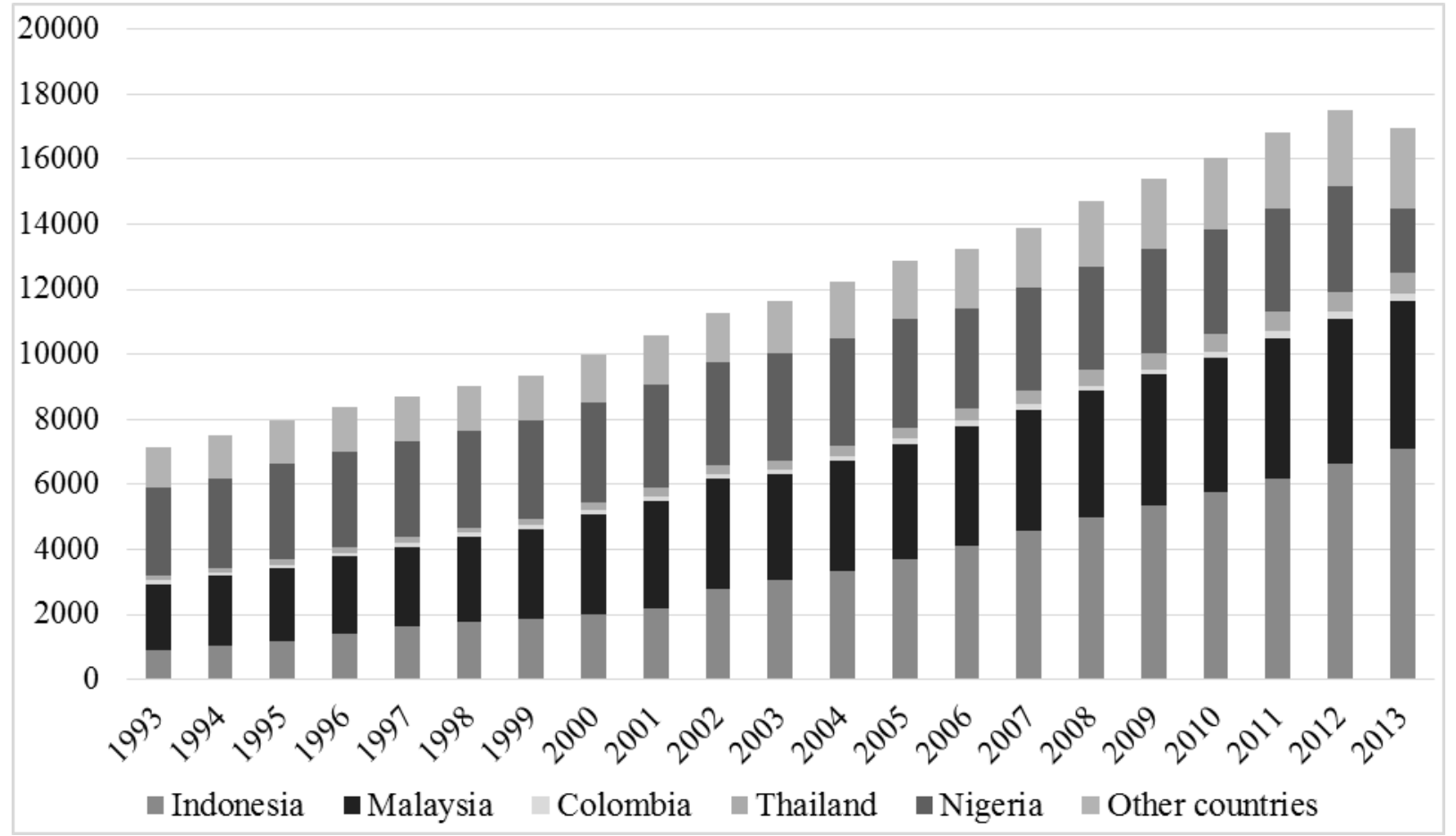

Source: FAOSTAT, accessed on Nov 2014

To begin the discussion on oil palm's increasing multiple uses, and thus flexing possibilities, it is necessary to first distinguish between the multiple uses of oil palm as an oilseed and those being developed as a major provider of biomass. In the past, the multiple uses of oil palm were tied to a series of co- and by-products obtained in the process of crude palm oil (CPO) and palm kernel oil (PKO) extraction and refinement. Indeed, CPO and PKO can be then further refined and processed as either edible oil for cooking or other industrial foods, biodiesel, or in personal care and household care products. These dynamics demonstrate that the main products and their by-products are not 
fixed; rather they are interchangeable within the flexing framework. Figure 2 presents the different pathways of CPO and PKO through refining.

Figure 2: Multiple uses of oil palm as an oilseed crop

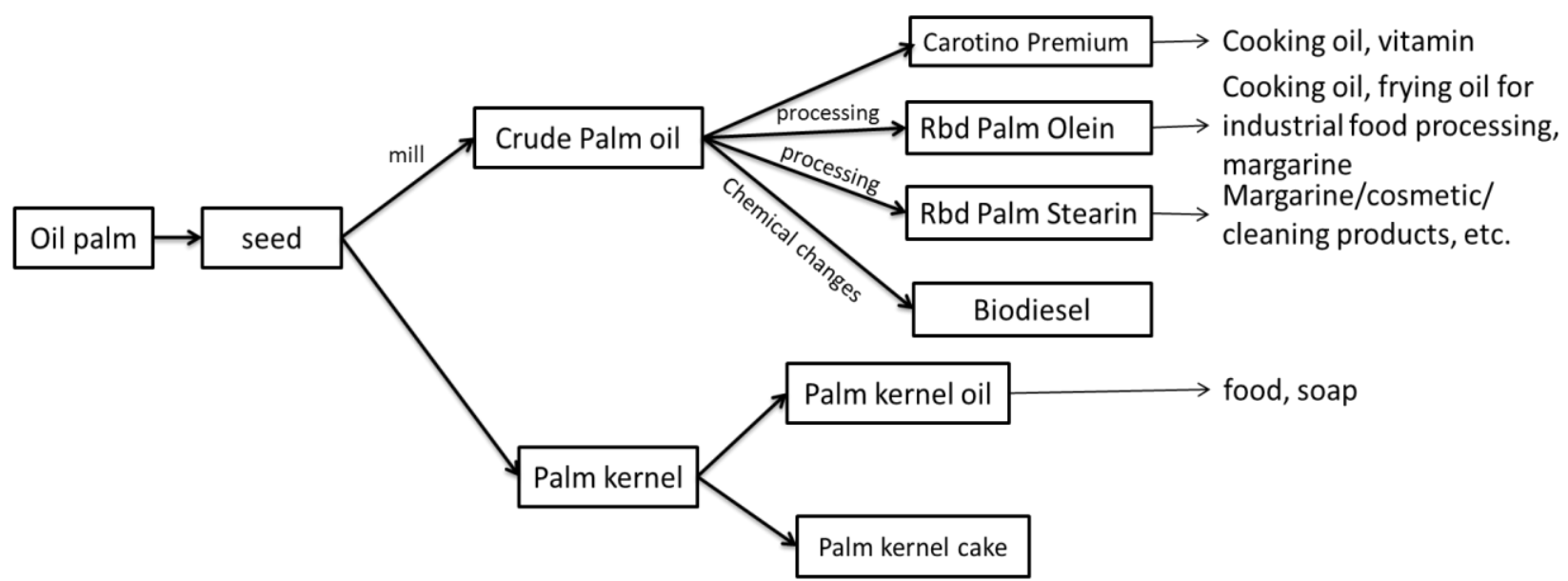

Source: Authors' elaboration.

Flexing occurs across the multiple uses of crude palm oil and palm kernel oil (and their byproducts), as represented in Figure 4. The oil palm mill is, therefore, the underpinning technology of the first generation of oil palm flexing. With the advancing of oleo-chemical techniques to further process $\mathrm{CPO}$ and $\mathrm{PKO}$ there has been an increase in the use of palm oil for industrial and food domestic uses worldwide, seen in Figure 3.

Figure 3: The industrial and food domestic use of palm oil worldwide (1000 Metric Tons)

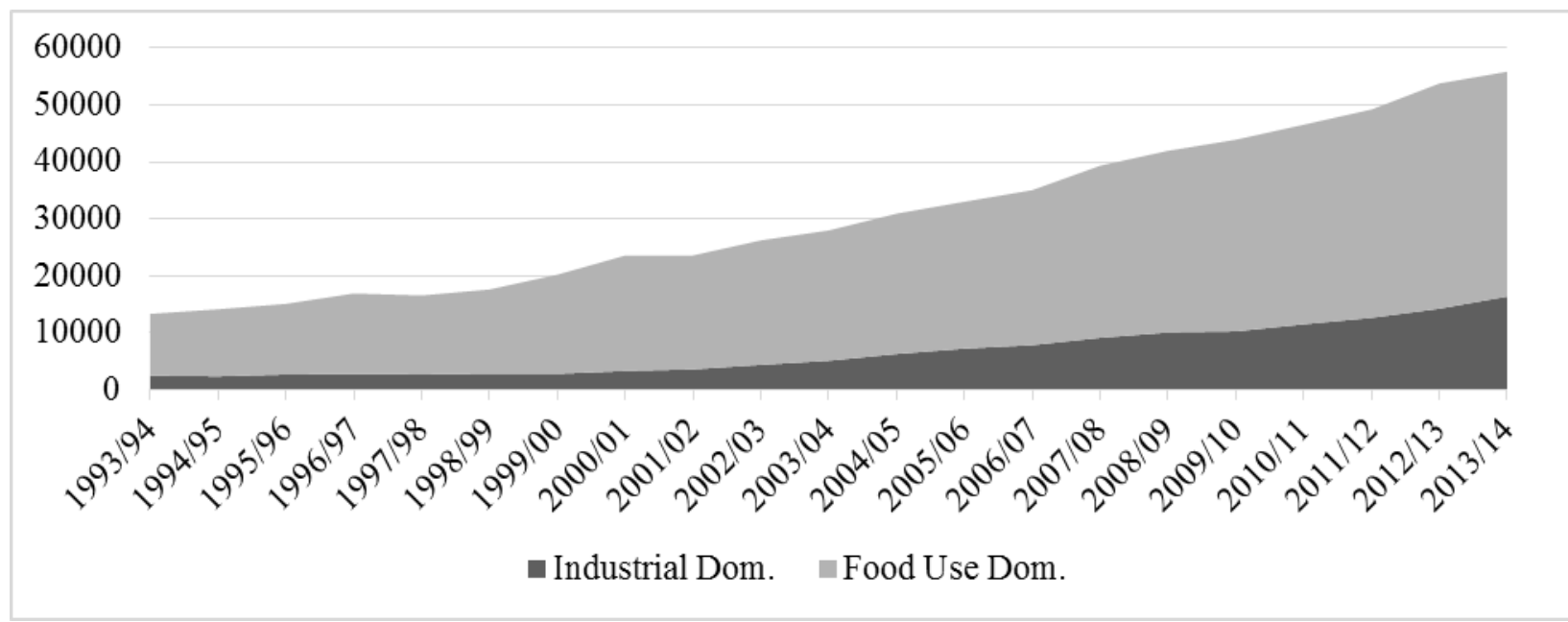

Source: USDA-FAS (1) data of 1993-2000: Oilseeds: World Markets and Trade (2006); (2) data of 2001-2013: Oilseeds: World Markets and Trade (2014) 
The percentage of industrial use of palm oil rose from 15\% in 2001 to $29 \%$ in 2014, implying a growing diversification of the commodity's multiple uses.

Such expansion in the multiple uses of oil palm, especially biomass ${ }^{3}$, is closely linked with major research and development efforts, carried out through public-private-partnerships and crystallizing in commercial ventures. These various uses are depicted in Figures 4 and 5 in the case of the technologically path-breaking Malaysian oil palm industry.

Figure 4: Multiple uses of oil palm as an oilseed and as biomass

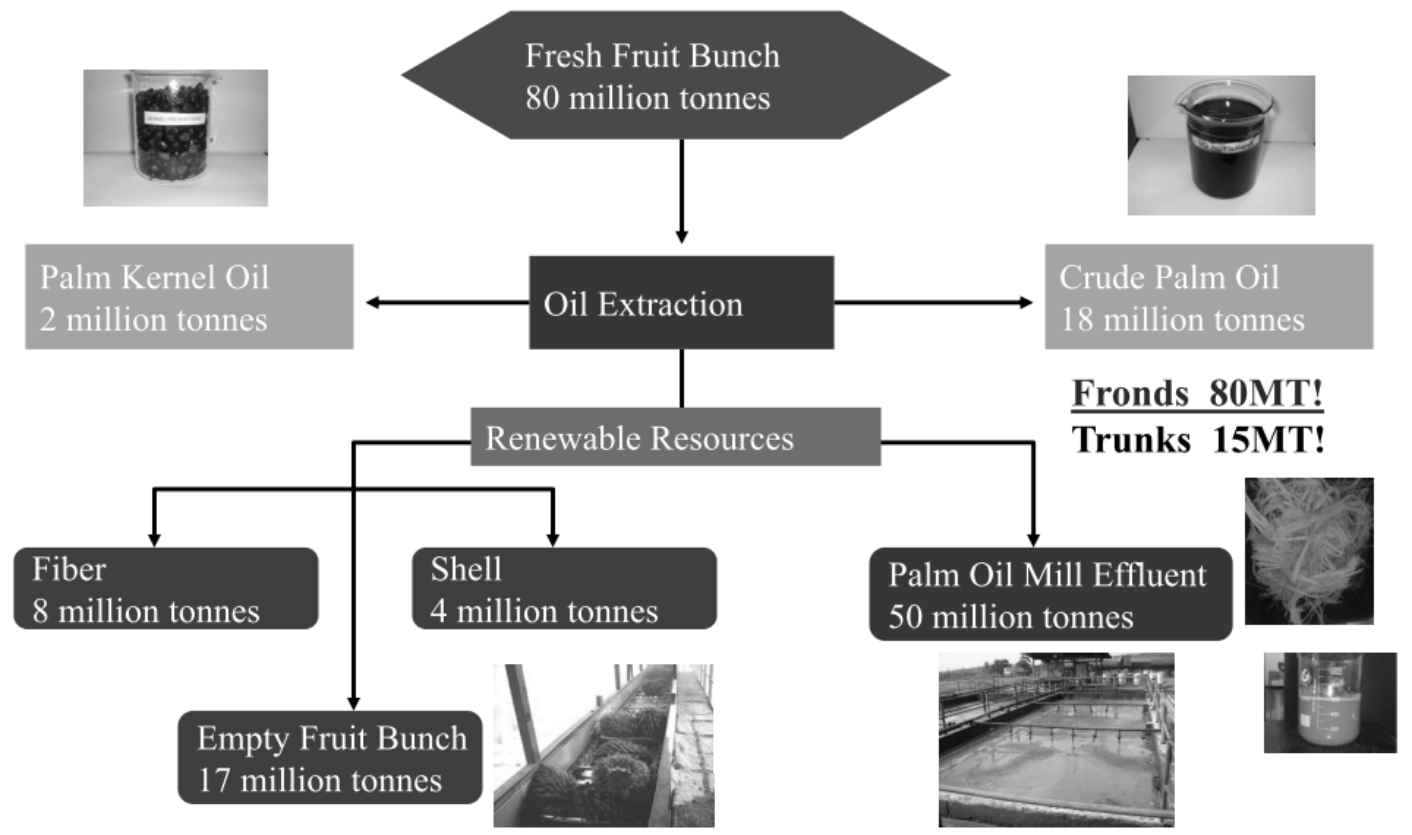

Source: Hassan and Shirai 2013

Besides alcohols being obtained as an oleochemical produce of palm oil (Corley and Tinker 2003, 25 ) it is now also possible to produce ethanol out of oil palm biomass (Loh and Choo 2013, 9). Empty fruit bunches and palm oil mill effluent (POME) are also used in 'fiber processing into mattresses, furniture-based manufacturing, pulp and paper-making, cement manufacturing, etc., besides being used for power generation in palm oil mills' (Loh and Choo 2013, 8). Biogas from POME is also starting to be used to generate electricity for industrial plants and to sell to the national grid (Loh and Choo 2013, 4).

\footnotetext{
${ }^{3}$ Including eempty fruit bunches, palm fronds, trunks, palm kernel shells and mesocarp fibers) (see Pogaku and Sarbatly 2013)
} 
Figure 5: Multiple uses of oil palm biomass as a source of bioenergy, biofuels and biomaterials

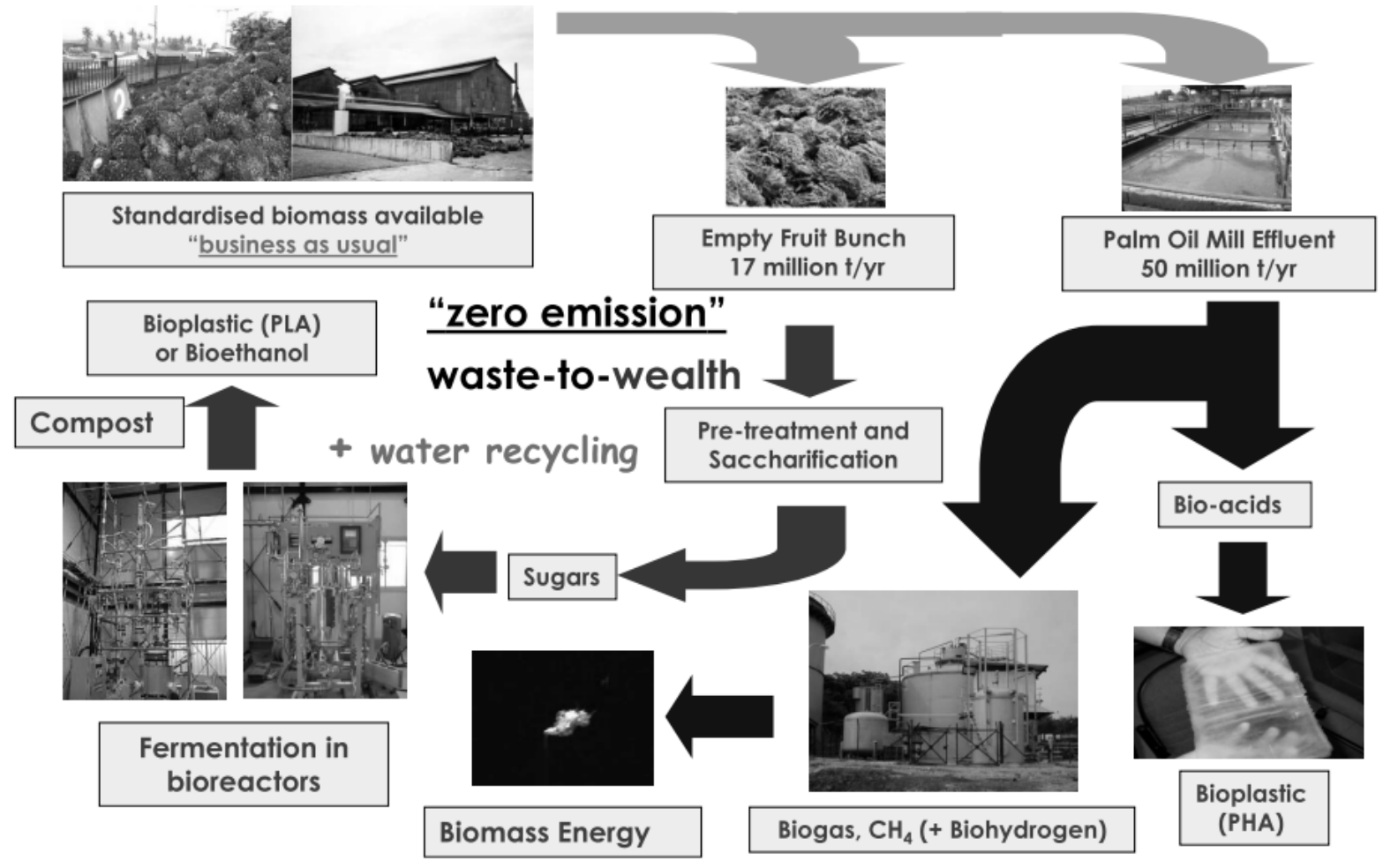

Source: Hassan and Shirai 2013

The "zero emissions" and "waste-to-wealth" messages presented in Figure 5 will be further problematized in the next section, where initial ideas regarding how flexing is occurring are discussed. For the time being, the (new) multiple uses of oil palm will be primarily emphasised here. The main point is that, if the oil palm mill is the central technology around which the first generation of palm oil use is based, the oilpalm bio-refinery will be the key underpinning technology in this second generation of flexing across a broader range of multiple uses. This second generation is emerging from the use of oil palm's biomass and from the new uses developed for the by-products generated during $\mathrm{CPO}$ and PKO extraction. This means there is no need to flex oil palm either into oil or biomass. Palm oils and oil palm's biomass are simultaneously available inputs for further flexing. As anticipated by Rexen and Munck in 1984, 'changing patterns of industrial demand based on generic constituents of crops suggest that agriculture will evolve toward integrated biomass production systems [via] agricultural refineries, which would undertake primary biomass processing' (in Goodman et al. 1987, 181 emphasis added).

As a result of the advancement of bio-refineries, the multiple uses are being further developed to follow two main technological paths, as depicted in Figure 6. One is that of the oil palm frond juice path. This allows for furthering biofuels-/bio-chemicals-based uses. Palm phytonutrients such as carotenes, vitamin E, squalene and sterols for pharmaceutical use can be extracted and produced out of palm biodiesel (Loh and Choo 2013, 11). The other is the lignocellulosic path, allowing also for 
more bio-chemicals-based uses such as bioplastics, nutraceuticals ${ }^{4}$ and others (Hassan and Shirai 2013). Altogether, these two future technological paths may lead to a "3.0" version in the flexing possibilities among the increasing uses of oil palm.

Figure 6: Main technological paths for further developing multiple uses of oil palm biomass
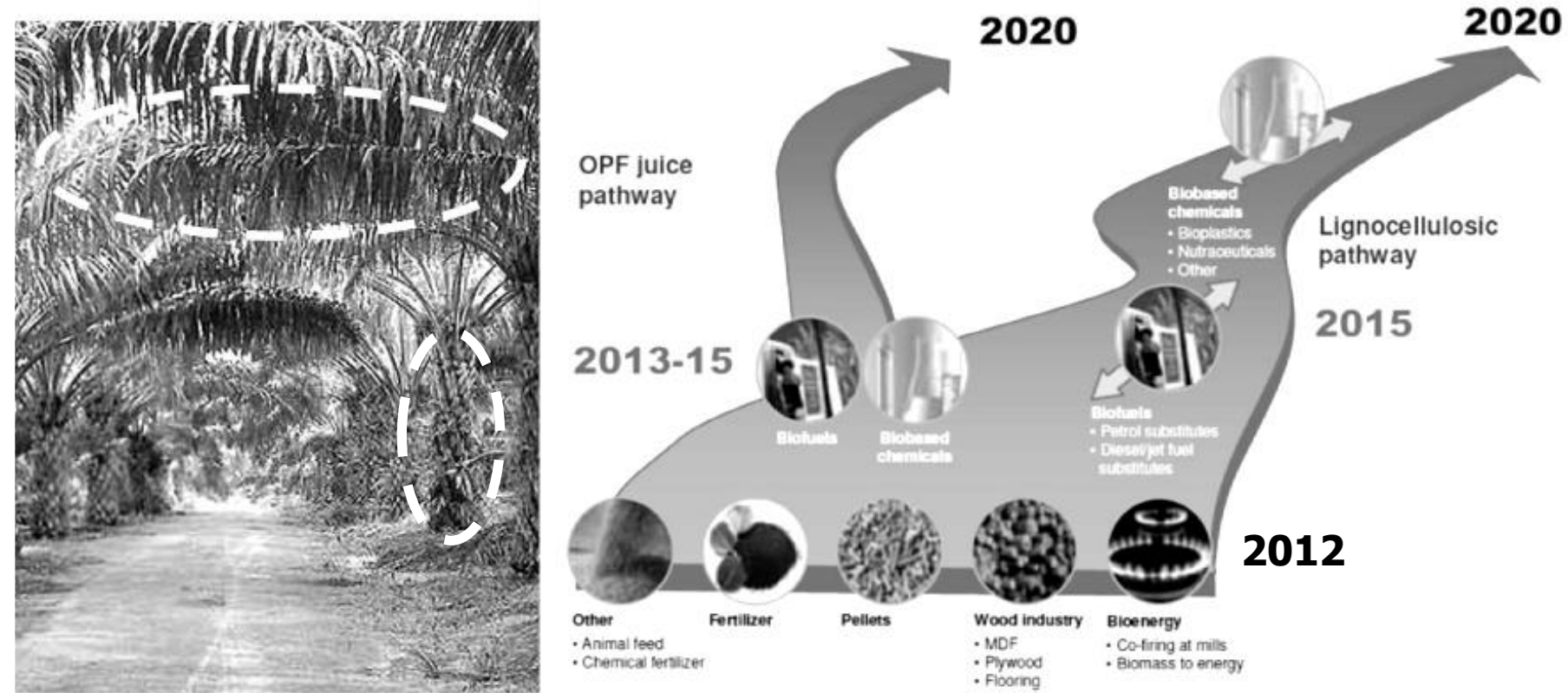

Source: Hassan and Shirai 2013

According to Borras et al., if a crop or commodity use can be switched from one specific purpose to another with technical ease and with attractive economic return, then it is not difficult to imagine [...] the far-reaching political economic implications when its multiple-ness meets flexible-ness' (2014,5 emphasis added). This section emphasised how oil palm meets the first of Borras et al.'s (2014) three 'minimum conditions' for multiple uses to be flexed, namely having the 'material basis' for multiple uses. In the following sections, Borras et al.'s third minimum condition for flexing, namely the 'profit viability' (2014), will be addressed. In so doing, the major politico-economic drivers and implications of turning oil palm's multiple uses into the commodity form, as a pre-condition for flexing, will be discussed first. Put differently, the next sections will present a preliminary examination of the why of oil palm flexing and of who gets to decide how it is flexed, by whom, when, and where.

\footnotetext{
${ }^{4}$ Such as C5 and C6 sugar molecules in oil palm biomass [...] to construct medium and long chain (higher) hydrocarbon chain chemicals' (Loh and Choo 2013, 12).
} 


\section{Why flex oil palm?}

This section proposes three major and deeply interconnected drivers of oil palm flexing today. The first is that of the accumulation imperative, the second is related to the green economy paradigm, and the third to changes towards a multi-polar world food and agro-commodities regime.

The first possible driver of oil palm flexing is one which connects to the latter two: the current world politico-economic conjuncture in which oil palm has been transformed from an agricultural crop into a highly appealing accumulation project. This is related to two intertwined dynamics. The first connects to crises of over-accumulation: As Harvey argues, 'Capitalism always requires a fund of assets outside of itself if it is to confront and circumvent pressures of over-accumulation. If those assets, such as empty land or new raw material sources, do not lie to hand, then capitalism must somehow produce them' (2003, 143). Flex crops such as oil palm, have become perfect outlets for surplus capital in search of new and/or safer investment frontiers.

The other element to this driver is related to Bernstein's review of the classic agrarian question in times of globalization, where he affirms that 'the range of non-agrarian, non-indigenous [local/national] sources of agrarian capital is likely to expand and diversify, and their significance to increase, over the history of capitalism' (2006, 10 stress added). The emergent flex crop and commodity complexes, and of oil palm in particular, are being targeted by increasingly financialized (agro)industrial and energy corporations, and by investment funds of different character ${ }^{5}$, following broader trends of financialization of agriculture (Isakson 2014) and of the world economy (Fine 2012). It is possible that this is occurring since flex crops also act as a flex-investment: they represent commodities which allow those investors who are in control of the different uses to selectively benefit from multiple values (whether it be in the commodity form of biodiesel, detergent, or pharmaceuticals) based on which is more profitable at what moment. As argued by Borras et al., 'financial capital may be particularly attracted to flex crops because their multi-functionality helps to negate the purported trade-off between risk and yield on investments' $(2014,7)$. In short, as a result of the financialised investment influx, the boundaries of the flex crop and commodity complexes are pushed towards new thresholds.

The second driver, the green economy paradigm, is connected to the first. As observed again by Harvey, nature and the environment are becoming a new frontier for capital accumulation faced with the increasing global environmental crisis: 'The escalating depletion of the global environmental commons (land, air, water) and proliferating habit degradations that preclude anything but capitalintensive modes of agricultural production have likewise resulted from the wholesale commodification of nature in all its forms' $(2003,148)$. In this sense, 'an entire philosophy of nature

\footnotetext{
${ }^{5}$ According to multiple speakers at the First Latin American Congress of Oil Palm Growers, October 17-18 2013, in
} Antigua Guatemala. 
co-produced with a new 'green' economy' (Fairhead et al. 2012, 245) has been advanced. Along with the frame that, 'growth in income and employment are driven by public and private investments that reduce carbon emissions and pollution, enhance energy and resource efficiency, and prevent the loss of biodiversity and ecosystem services' (UNEP 2011, 16).

For instance, linking the green economy back to the most recent biofuel boom since the mid-2000s (Nalepa and Bauer 2012) palm oil is increasingly used as biofuel feedstock: 'from zero in 2000 to about $10 \%$ of crude palm oil in 2011' (Sayer et al. 2012, 115). Within this biofuel boom, the new multiple uses of oil palm's biomass become profitable and are highly promoted in search of 'extra flexibilities from mainly non-food biomass in global value chains' (Borras et al. 2014, 2). Thus, the uses of palm oil and oil palm's biomass shape and are shaped by the green economy paradigm, which in essence pushes for the flexing of oil palm as an economically desirable and environmentally sound accumulation project.

Finally, we see oil palm flexing as embedded within the current changes towards a multi-polar world food and commodities regime, in which the BRICS and MICS countries play an increasingly relevant role (see inter alia McMichael 2012, White et al. 2012, and Margulis et al. 2013). This argument has various elements to it. One relates to the value of certain commodities in the current phase of world capitalism, and another connects to the growing relevance of emerging powers in the global political economy. The first element, briefly discussed above, is regarding the possible key features making oil palm an increasingly valuable crop today. The second element has to do with BRICS and MIC countries becoming not only major producers and consumers of the multiple products of oil palm, but increasingly mega-hubs of their trade too. A good example of a new key player in the world political economy of oil palm is China. As depicted in figure 7, China and India take the lead of palm oil importing since the last decade. As the world's largest importer of palm oil in the recent years, India captures nearly $20 \%$ of the world's exports while China has a portion of nearly $13 \%$ as of the fiscal year 2013/2014. 
Figure 7: Palm oil imports by China, India and EU-27. 1999-2014 (1000 MT)

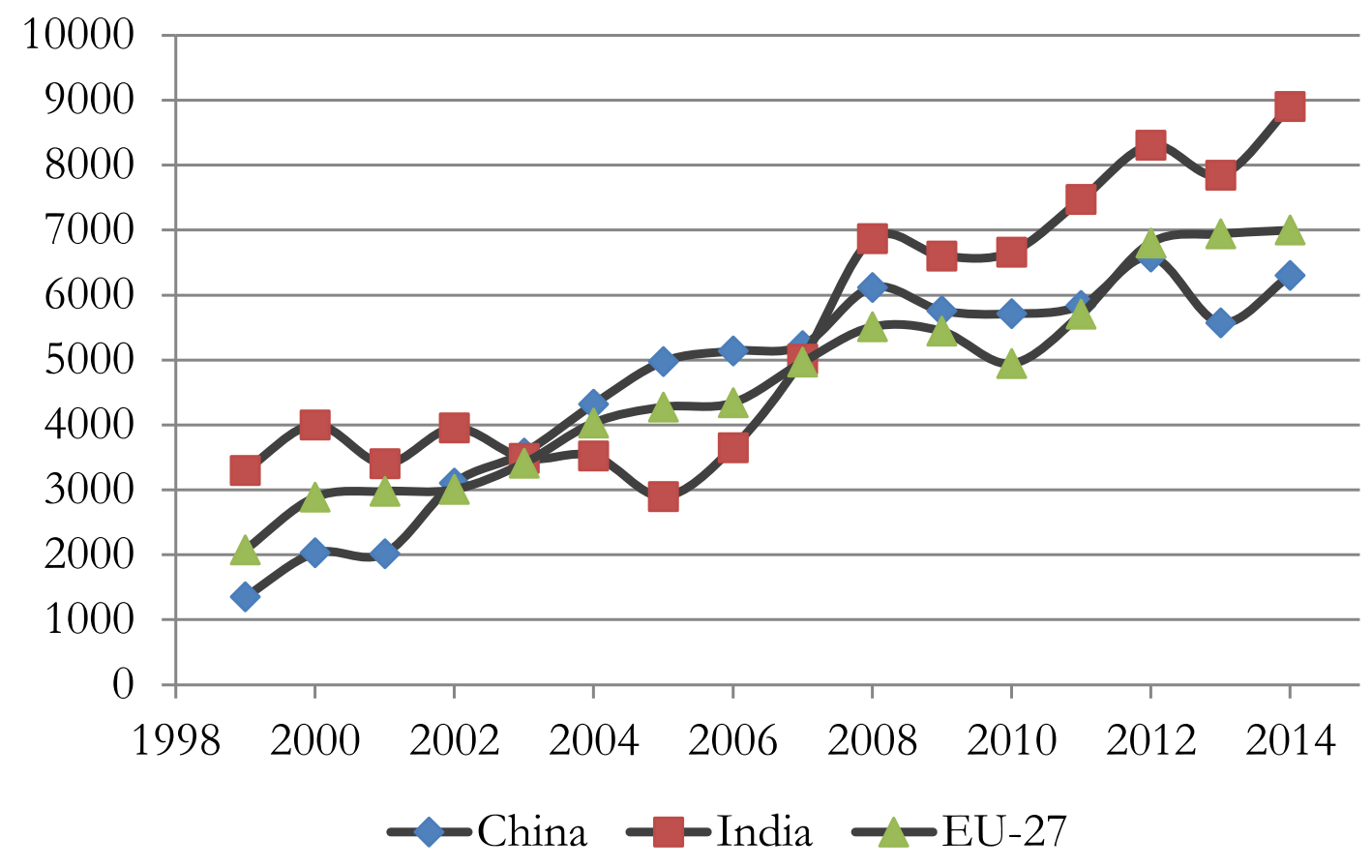

Source: USDA-FAS 2014, calculated from the imports by India and China and the total world exports.

The high demand for palm oil in China is forecasted to keep at pace in the long run, although there are still many uncertainties and fluctuation possibilities in the market. For instance, the lower prices for soybean and rapeseed oil in late 2013 have put pressure on palm oil consumption and import growth in China, while the 2007/08 global food price surge created a great demand for palm oil. However, the full reasons could not be reduced to market price elasticity. Demand for palm oil in China remains strong mainly because of its inexpensive price relative to soybean and rapeseed oils. Blending palm oil with other vegetable oils for cooking is popular in China; as it is also its use in industrially processed foods like instant noodles, snacks, biscuits and so on. As shown in Table 1, around 37\% of China's domestic consumption of palm oil in 2013 was non-food industrial use in cosmetics, paints, candles, household cleaners, etc., and this changed from 17\% in the year 2000 . The palm oil that is imported to China has yet to be used for biodiesel directly. However, statistics and tax adjustments from customs show that there are imports of palm oil linked to biodiesel markets in Southeast Asian countries (USDA 2013, GACC 2013, Reuters 2013, Ng 2014); therefore, real palm oil consumption in China is even greater than assumed if the feedstock of imported biodiesel is taken into consideration. 
Table 1: Food, industrial and total palm oil consumption in China, years 2000, 2005, 2010 and 2013 in absolute and relative terms

\begin{tabular}{|l|r|r|r|}
\hline Year & $\begin{array}{c}\text { Food use (1000 MT/\% } \\
\text { over total) }\end{array}$ & $\begin{array}{c}\text { Industrial use (1000 MT/ \% } \\
\text { over total) }\end{array}$ & $\begin{array}{c}\text { Total domestic consumption } \\
\text { (1000 MT) }\end{array}$ \\
\hline 2000 & $1688 / 83 \%$ & $340 / 17 \%$ & 2028 \\
\hline 2005 & $3074 / 62 \%$ & $1900 / 38 \%$ & 4974 \\
\hline 2010 & $3717 / 64 \%$ & $2080 / 36 \%$ & 5797 \\
\hline 2013 & $3600 / 63 \%$ & $2150 / 37 \%$ & 5750 \\
\hline
\end{tabular}

Source: Based on USDA 2013.

The next section builds on this general framing of the drivers and looks towards the actors involved in shaping the flexing of oil pam, their rationales, aims, and the ways they relate to one another.

\section{How does oil palm flexing work, and who controls it?}

Oil palm flexing can be either 'real' (actually happening) or 'speculated' (when it is not happening yet but it is feasible and likely to occur) (Borras et al. 2014, 8) ${ }^{6}$. Bearing this in mind, this section presents some preliminary ideas about how real or speculated oil palm flexing happens, paying particular attention to when and where in the world and in the value web it happens.

There are two possible and mutually recursive realms involved in the flexing of a crop or a commodity, namely the material and the ideational. As elaborated by Borras et al. (2014), for a crop or commodity to be flexed it is necessary for it to meet the three minimum conditions, namely, material basis, technological feasibility and profit viability. These material conditions are, nonetheless, usually strengthened or realised with ideational ones through legitimating discourses. These discourses include those categorized by Borras et al. ${ }^{7}$ as 'flex policy narratives by governments and corporations' (2014) in defense and/or promotion of the flex crops and commodities complexes. The narratives are rarely presented in an isolated way. Most often they are deployed in a 'discursive flexibility' fashion, that is, through 'the ability to strategically switch among multiple legitimating discourses which construe the necessary meanings and representations to achieve an objective' (Hunsberger and Alonso-Fradejas 2015). These material and ideational conditions do not emerge from a vacuum, rather they are embedded in the complicated social-political context which is shaping and is shaped by the different interlinked actors.

\footnotetext{
${ }^{6}$ Borras et al. also consider 'imagined flexing' to mean 'flexing that is not real, not actually happening and has no material or logical basis, yet it is invoked for some reason' $(2014,9)$. We found no clear examples of this type of flexing in the case of oil palm but this, of course, remains an open empirical question.

${ }^{7}$ Building on an earlier analysis by Franco et al. (2010) on biofuels.
} 
To understand the workings of real or speculated oil palm flexing through a critical political economy lens it is necessary to dive deeper into who informs, decides, and controls the nature of flexing. An initial attempt of this is done below with a brief and broad analysis of different roles played by state, corporate (private) and social actors in the flexing of oil palm.

\section{State actors}

State actors are key players influencing the character and scope of oil palm flexing. They are usually responsible for setting the necessary material and ideational conditions for corporate actors to flexi or at least to kick-start it. In so doing, they rely on a series of mechanisms ranging from different sorts of regulatory toolboxes and legitimating discourses, to funding and/or subsidizing research, technology and infrastructural requirements for flexing to happen in lucrative ways. An in-depth examination of such mechanisms, and more generally on the entrenched interests of state and corporate actors in the oil palm value web, deserves further empirical investigation which goes beyond the possibilities of this paper. Nonetheless, we aim to illustrate here the role played by selected state actors from BRICS and MIC countries in Asia and Latin America in setting fundamental conditions for oil palm flexing. For explanatory reasons, an analytical distinction is made between two main sets of actions by state actors, regardless of the particular mechanism used. The first set involves actions to develop and strengthen the abilities of the oil palm industry to profitably flex. The second set includes actions seeking to legitimate oil palm's multiple uses, and the flexing among them, in society ${ }^{8}$.

First, state actors promote the flexing abilities of state, private or public-private oil palm-related industries. Among the many initiatives of its kind around the world, the case of Colombia's 2008 National Biofuel Policy is an example of how the government can facilitate appropriate conditions for flexing among the multiple uses of palm oil in national markets. As depicted in Figure 8, from the enactment of the biofuel policy onwards demand of palm oil for biodiesel in Colombia increased from $5 \%$ in 2008 to $42 \%$ in 2012 . This opened the possibility for corporate actors to flex among food, biodiesel and other non-food uses of palm oil. Furthermore, according to the Secretary General of the Colombian Federation of Oil Palm Growers (FEDEPALMA), the stability conferred by the increased domestic demand of palm oil has been key for Colombian oil palm agribusinesses to expand operations and search for a bigger share in world markets ${ }^{9}$.

\footnotetext{
${ }^{8}$ On the dual and contradictory role of state actors in capitalism more broadly see Fox 1993.
}

${ }^{9}$ Interview in Bogotá, September 202013. 
Figure 8: End uses of national production of palm oil in Colombia 2002-2012 (1000 tonnes)

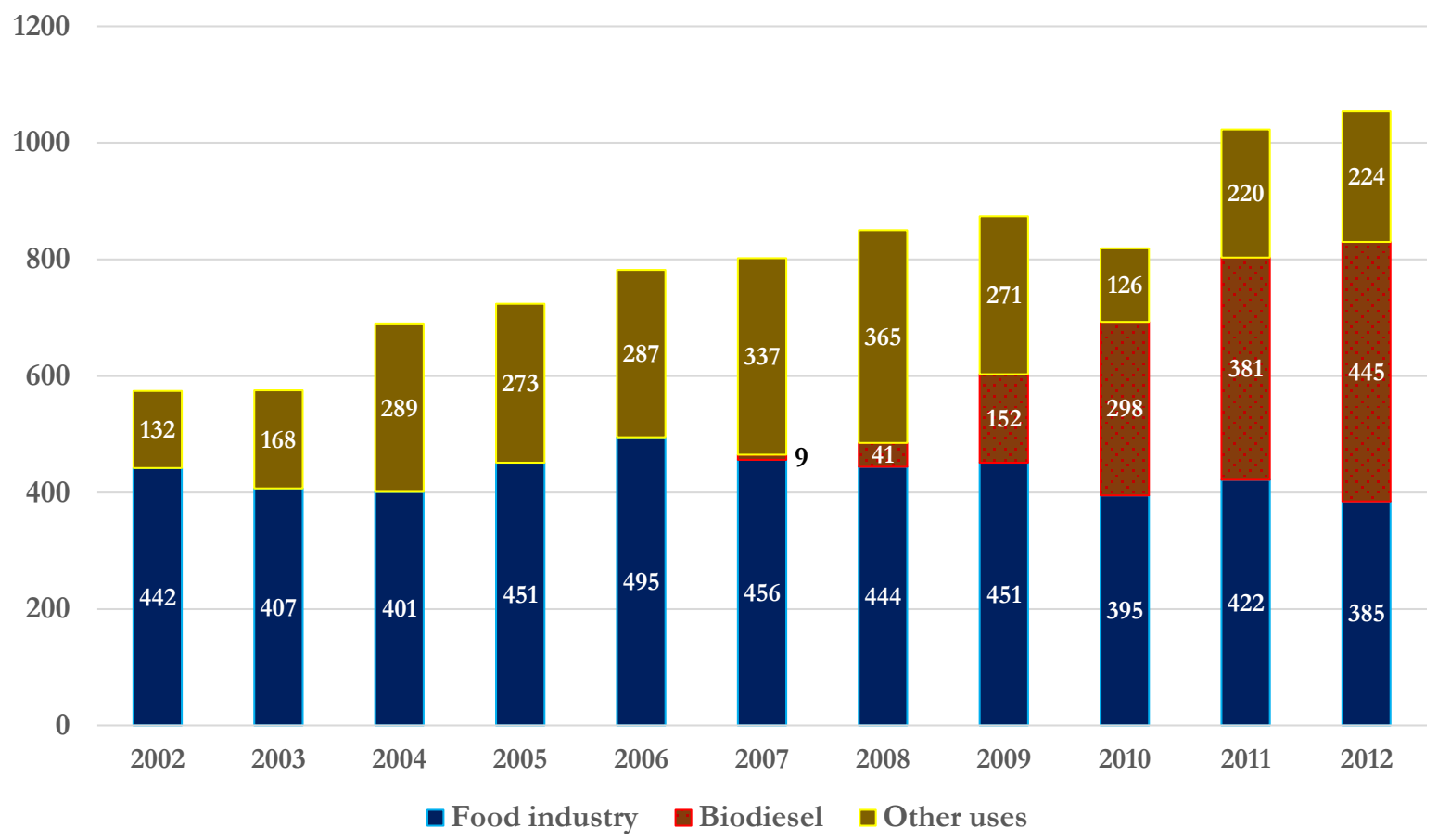

Source: Based on FEDEPALMA 2013.

The case of Malaysia's National Biomass Strategy 2020, which included the establishment of an international Oil Palm Biomass Center (OPBC), illustrates the role of different state actors in setting up conditions for flexing among the multiple uses of oil palm's biomass. The OPBC in Malaysia is not only the first of its class in the world, but also a major example of public-public, private-private and public-private partnerships in the context of current changes towards a multi-polar world food and agri-commodities regime. On the one hand, the Malaysian OPBC included many parties from the private sector ${ }^{10}$ and the academy ${ }^{11}$, most distinctively from Asia and Europe. And, according to a Malaysian government representative,

'Many plantation players that have abundant source of oil palm biomass are afraid to take up such high risk [of turning the biomass into commodities] given lack of research and proven cases for them to benchmark upon. [Thus] the OPBC "future" technology and intellectual property findings could pave the way for potential joint-ventures between the local oil palm plantation companies and international biochemical companies' (The Star, March 21 2012).

On the other hand, Malaysia is not only a recipient but also an overseas investor on the multiple uses of oil palm. On 2013, the government of Malaysia granted a US\$ 100 million credit at a very

\footnotetext{
${ }^{10}$ Including 3 major palm oil companies (Sime Darby, IOI, Felda) with globally leading technology developers interested in biomass utilization like Purac (The Netherlands), Novozymes (Denmark), LG Chemical (Korea) and others (Be-Basic 2014)

${ }^{11}$ Like the technical universities of Malaysia (UTM) and Delft (TU Delft-Netherlands), University Putra Malaysia (UPM), Standard and Industrial Research Institute Malaysia (SIRIM), Palm Oil Industry Cluster (POIC) Sabah, and Wageningen University (WUR-Netherlands) (Be-Basic 2014.)
} 
low interest rate to its Honduran counterpart to expand oil palm plantations, and to build the first large scale palm oil biodiesel plant in Central America in 2014 (La Tribuna,_March 26, 2013).

Besides, international regulatory instruments and bi-lateral, regional and multilateral agreements (on investment, trade, (technical) cooperation, intellectual property, and so on) all shape the domestic environment for oil palm flexing. For instance, the 2013 EU-Central America Association Agreement formalized the previously unilateral favorable market access conditions for Central American palm oil to the EU. However, it was crude palm oil exports from Honduras (ICEX 2013) and Guatemala (Central America Link, December 26, 2013), and not of any further transformed commodity, that increased. On the contrary, China's adhesion to the World Trade Organization (WTO) from 2006 onwards finished with the quota system for palm oil imports, leading to their increase and to the broadening of the possibilities for flexing among the multiple uses of palm oil.

But domestic regulatory and institutional frameworks can also impact the international dynamics of oil palm flexing. For example, in the context of the greenhouse gas emissions reduction targets of the US and the EU, the currently strict requirements in the EU and the US regarding indirect land use change and its impact on the calculations of greenhouse gas emissions reduction, have curtailed the international biofuel market for major palm oil producers in South East Asia and Latin America. This led these countries to develop domestic blending mandates more recently (2008 in Colombia, 2009 in Malaysia (Loh and Choo 2013, 6) and 2014 in Indonesia) ${ }^{12}$.

Another important example is related to energy and food security policy in China. The $12^{\text {th }}$ five-year plan of the National Energy Administration (NEA) on Biomass Energy, states that China will develop non-food grain supplies for liquid biofuels and establish production and demonstration basis for non-grain liquid biofuels. The unstable supply of domestic feedstocks (basically used cooking oil) was thought to be hindering large-scale biodiesel production in China, so in 2013 under trade agreements with the Association of Southeast Asian Nations (ASEAN), a tax-free biodiesel shipment from Indonesia and Malaysia was implemented. Importers were mostly private companies. Complaints from the big state palm oil refiners quickly resulted in a consumption tax on imported biodiesel from the beginning of 2014 to secure the domestic demand on vegetable oil and biofuels as well as the interest of domestic industries. The imports for biodiesel fell after the taxing of blended fuel, but remain at relatively high levels. Thus, the Chinese state manages its tariffs and trading policies around crude palm oil and palm oil biodiesel to secure the domestic demand on vegetable oil and biofuels. This energy policy, together with the food security policy in the context of the current 'Going Out' approach to investment, has led the Chinese government to encourage public and private companies to invest in oil palm plantations in Indonesia and Malaysia, and to support them to increase their control on the oil palm value web from production to transformation, circulation, and consumption.

\footnotetext{
12 Indeed, at least according to Latin American oil palm industry representatives, national markets are more stable and easier to influence. They allow for the strengthening of the companies' capacities before going abroad, and save the insurance and freight costs associated to exports (Colombian FEDEPALMA's President in XVII International Conference on Palm Oil in Colombia, September 26 2012, and Guatemalan GREPALMA's and Ecuadorian ANCUPA's Executive Directors, in I Latin American Conference of Oil Palm Growers, Guatemala, October 182013$).$
} 
Secondly, and linked to the first set of state actions, is the legitimation of oil palm's multiple uses and of the flexing among them. In short, state actors on their own or together with corporate and social actors, actively work in broadening societal perceptions of oil palm's multiple uses from just a new set of accumulation projects, to main contributors to food and energy security, climate change mitigation, and (rural) development (Hunsberger and Alonso-Fradejas 2015). Take Colombia's 2008 National Biofuel Policy as an example, discussed previously, where it was framed as a means to achieve national energy security and rural employment goals ${ }^{13}$. Another example is the Malaysian Oil Palm Biomass Center, which the government claimed would contribute to the creation of 'economic value and to reduce Green House Gas emissions' (TU-Delft, November 21, 2011). Accordingly, the "zero emissions" and "waste-to-wealth" messages of the oil palm biomass bio-refineries are instrumental to this broader understanding of flex crops and commodities. In the same line, the Chinese government legitimates its international investments in and around the oil palm value web as a means to achieve national energy and food security. These national framings are amplified and supported by similar discourses held by international governance institutions, like the World Bank in the case of food security (2007), and UNEP with regards to the green economy paradigm (2011).

Further analysis is required into the relationship of state actors' action on oil palm flexing, especially members of the BRICS and MICS countries, together with the role of supra-national regulatory and financial institutions, overseas development cooperation agencies, and the interactions among all of them.

\section{Corporate actors}

Corporate actors are strategically situated around the oil palm value web, each involved in one, some or all the elements of flexing among its multiple uses. For instance, there are many important Malaysian and Indonesian oil palm companies involved in the production, processing, trading, etc. of oil palm and crude palm oil. However, they are not all involved in further processing of palm oil or oil palm's biomass, and therefore, in flexing. This leads to question: given the high cost of biorefineries, who among the corporate players is most likely/or best prepared to actually flex among the multiple uses brought about by these new technologies? In other words, who in the long run will control oil palm flexing throughout its complex and expanding value web?

As a preliminary discussion, we emphasise here the highly financialised, transnational corporate actors repositioning themselves globally to capture a higher amount of control in activities within the oil palm value web. Often, transnational corporate players form this in alliance with corporate actors from oil palm producing countries. They do so as part of their own corporate strategy and/or in response to governmental regulations, like in Malaysia where 'the Government is strongly encouraging local plantation companies to undertake joint ventures or become stakeholders in the new downstream activities [around oil palm's biomass] rather than just becoming a supplier to the

\footnotetext{
${ }^{13}$ Interview with the Biofuels Program Coordinator of the National Planning Department, Government of Colombia, in Bogota, July 2008.
} 
downstream operators' (The Star, March 21, 2012) Take the strategies of Unilever, Cargill, Yihai Kerry-Wilmar International, and the Chinese Julong Group as examples.

Unilever is an Anglo-Dutch manufacturer that is 'the world's largest multinational consumer goods buyer of palm oil' (Unilever 2013b, 13). In fact, Unilever 'purchases around 1.5 million tons of palm oil and its derivatives annually, which represents about $3 \%$ of the world's total production' (Unilever 2013a), and the majority of the crude palm oil Unilever bought is from the giant Wilmar, which holds $71 \%$ of its plantations in Indonesia, 24\% in Malaysia and 5\% in Africa (Wilmar 2013). In other words, Unilever is heavily involved in the oil palm value web, but whether they are involved in the flexing is yet to be seen. Why have they (if they have at all) decided to engage in flexing the commodity, and how would this help in the company's expansion? In our view, Unilever's ability to flex is certainly present, so how and to what extent they will use this position as a major buyer of oil palm-derived commodities to feed their industrial production requires further analysis.

Cargill is the largest privately-owned company in the US and one of the biggest agricultural traders in the world. Cargill is deeply involved in the palm oil value web from production, to transformation, and circulation until it is traded to the product manufacturers, the food service industry and the wholesalers. Cargill can decide when to flex what, based on their vertical integration into palm oil production. They can either sell it, after its initial processing, in the biofuel format, or as a fat, or edible oil. They are in fact an important player in the oil palm's value web starting from the plantations owned by Cargill's oil palm subsidiary - CTP Holdings - with land holdings in Indonesia and Malaysia ${ }^{14}$. On these plantations they also engage in crushing in their own mills. At this stage they also buy from other suppliers in both countries. Cargill owns transport and shipping subsidiaries which move the commodities from the production site to further refining and blending plants. Before palm oil is refined, traders and brokers work with its derivatives and sell it to various customers. After refining, it is shipped to the ingredient manufactures where it is then processed further. Palm oil might also be sent to product manufacturers before it makes its way to the retailers (i.e. Walmart), the food service industry (i.e. McDonalds), and to the consumers' basket or belly. As depicted in Figure 9, Cargill has mills on sight where their production takes place, while their other processing plants are located in the US, Mexico, Europe, India, and Malaysia, which shows the company's geographical involvement in the oil palm value web (Cargill, 2013).

${ }^{14}$ Cargill's own volume from its plantations accounts for 3\% of the total global flow (Cargill, 2013). 
Figure 9: Cargill's refining and crushing plants worldwide
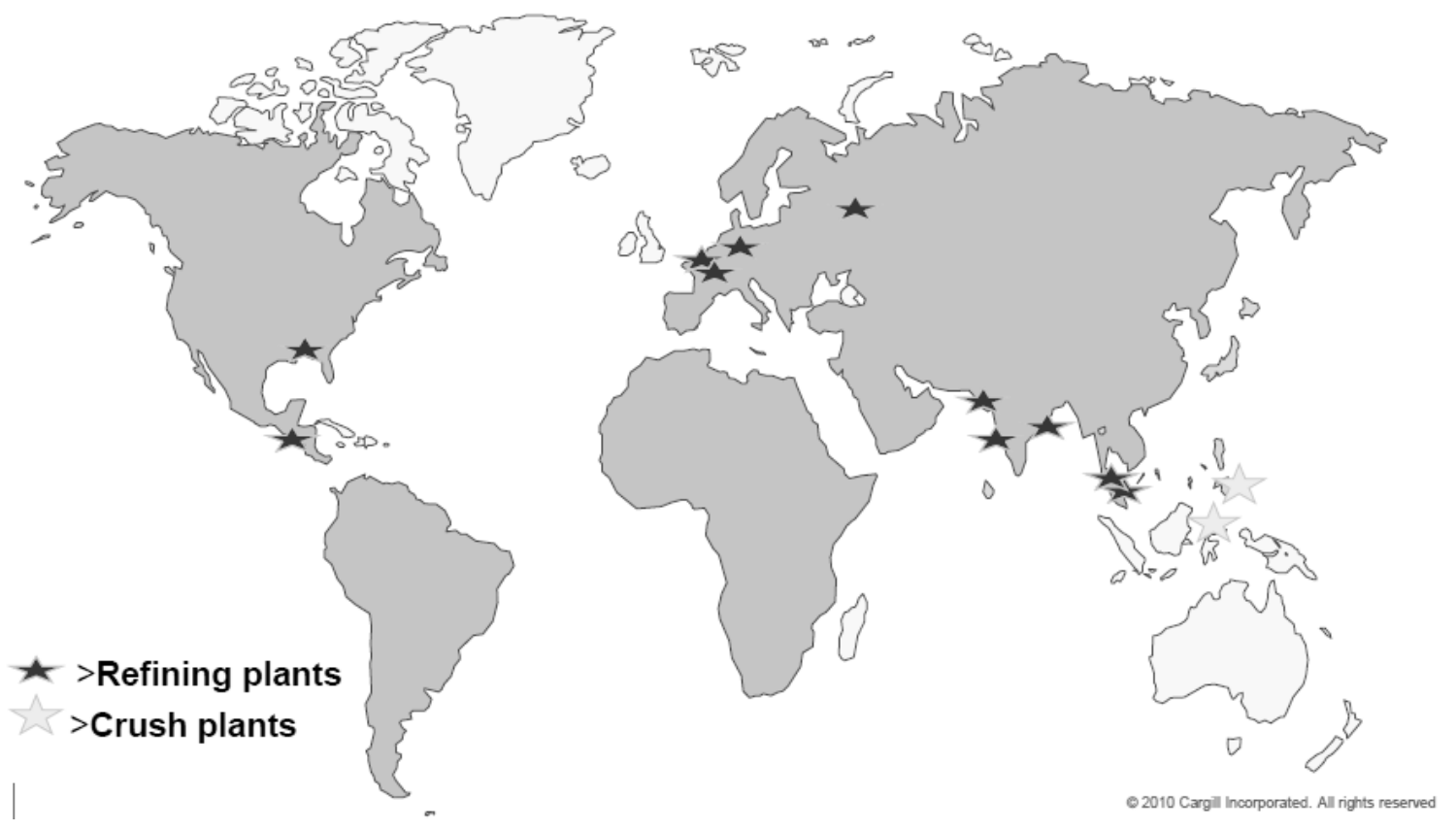

Source: Cargill 2010

Cargill's main trading vehicles are located in Singapore along with their financial agencies which are fundamental to 'raising funds for investments in new holdings and infrastructure, and in facilitating key mergers and acquisitions between companies' (ZSL Indonesia, 2012). In short, it can be said that Cargill is flexing among the many intermediate and final uses of palm oil commodities through its various physical uses and its financial derivatives. The involvement is deepened based on access to information regarding crop shortages and surpluses which helps set the price of commodities. This in turn would inform decisions regarding what form the commodity should be sold in. At this time, it is difficult to discern when the commodity is used for which function, however, it is clear that flex commodities can be used interchangeably by companies via subsidiaries and the channels within which the commodity moves. One question which requires further research is whether Cargill is involved or potentially interested in exploring the flexing possibilities of oil palm biomass.

Yihai Kerry, a subsidiary of the Indonesian capital-controlled Wilmar International, has been operating in China since the late 1980s when it began its cooperation with COFCO, a state corporation, in the context of the 'bring in' approach to foreign direct investment of the Chinese government. After a series of very complicated joint-ventures, mergers and acquisitions with COFCO, KUOK Group, ADM, and others, Yihai Kerry now penetrates multiple market segments in China. The company is especially focused on oilseed crushing, edible oils refining, consumer pack oils, specialty fats and oleo-chemicals manufacturing, with over 170 large-scale integrated manufacturing plants located in 43 strategic locations in China, as well as an extensive nationwide sales and distribution network. As a subsidiary of Wilmar international, Yihai Kerry holds priority in raw material sourcing from Malaysia and Indonesia. Therefore, a fully integrated palm oil value chain is controlled by Yihai 
Kerry and Wilmar International, which allows them to minimize the costs of production, handling and logistics, and creates flexibility for them to adjust the portfolio of end-products according to Chinese markets' signals. Although there are some clues indicating that Yihai Kerry also invests in biodiesel production, further research is needed since there is no official data or statement to trace the actual business. Indeed, it would be interesting to inquiry about to what extent does Yihai Kerry flex among the multiple uses of palm oil, whether Yihai Kerry is actually or potentially interested in exploring the flexing possibilities of oil palm biomass, and more broadly, to understand why Wilmar International decided to expand into China in the 1980s and what does this mean for their abilities to flex among oil palm's multiple products today.

Last but not least, with the highest palm oil market share in China, is the case of the Julong Group. This company developed its overseas oil palm production with the establishment of plantations in Indonesia and Malaysia in $2006^{15}$, followed by a crushing plant in 2011, in the context of the current 'going out' approach to foreign direct investment of the Chinese government. Julong Group is also involved in downstream flexing of palm oil's multiple uses after it is imported to China. As depicted in Figure 10, palm oil is used as either a commodity hedging in the futures market ${ }^{16}$, or sold directly to other companies as an industrial input. After refining and fractioning, the destinations for palm oil include the cooking oil retail and wholesale markets, as well as biodiesel after further processing (there is a need to explore whether and to what extent is the Julong Group interested in flexing oil palm's biomass). Julong Group's vertical and horizontal integration in the oil palm's value web increased its flexing abilities by developing uses of the commodity which are not necessarily complying with "China's food security principles". It is difficult to trace all the possible uses of palm oil once in China; but it can be said that it is the large, private transnational corporations, rather than the state, that is in control of the palm oil flexing process in China. Considering that most other "food" imports, like soybeans, are under control of the state or state-owned companies, it is worth interrogating why this is not the case for palm oil, and what is the actual role played by the Chinese state. Furthermore, why is it that Julong Group's plantations are in Indonesia and Malaysia, and not in some of China's southern provinces with accurate climate conditions (like Guangxi, Guangdong, Fujian or Hainan)?

\footnotetext{
15 So far, Julong Group has developed oil palm plantations with a total area of 100,000 hectares as well as reserve land with a total area of 100,000 hectares (partly in Indonesia and partly in Malaysia), an additional area of 10 thousand hectares of oil palm is contracted with smallholders in the local communities (Julong China 2013)

16 The Chinese General Office of the State Council, 2007[59] encouraged the establishment of futures market for palm oil.
} 
Figure 10: Industrial Chain of Julong Group China

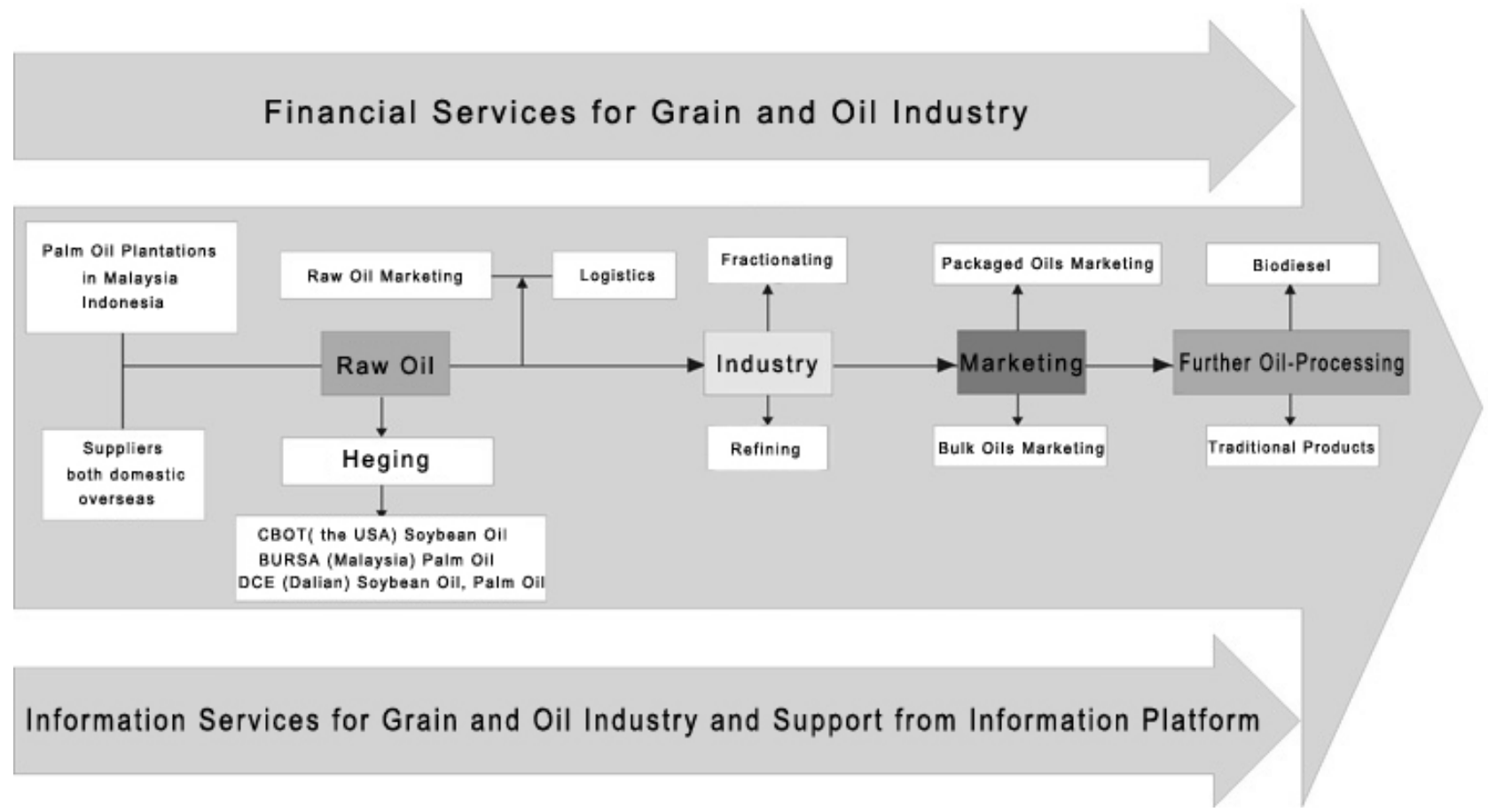

Source: Julong China 2013.

Questions remain as to what extent the ways of doing business differ among TNCs from NorthAtlantic countries and those from the BRICS and MICs, and what all these actors have in common. The answer to the latter, at its simplest, is their aim to capture a greater share of and around the oil palm's value web by increasing both, vertically and horizontally, their abilities to flex among oil palm's multiple uses. In doing so, besides demanding further institutional, regulatory and discursive support from the state, corporate actors are developing their own regulatory systems to present themselves in society as socially and ecologically responsible businesses. Most distinctively, and very much in line with current developments of multiple uses for palm oil and oil palm's biomass, many corporate actors are members of two main global corporate social responsibility (CSR) initiatives around the oil palm value web, namely the Roundtable on Sustainable Palm oil (RSPO) and the Roundtable on Sustainable Biomaterials (RSB). Corporate actors often collaborate with civil society organizations to enhance and spread these private regulatory systems. The following discussion proposes some ideas about the particular role played by these social actors in the flexing of oil palm.

\section{Social Actors}

With the risk of oversimplifying a rich and dynamic mosaic of political rationalities and responses of various social actors to current dynamics of oil palm flexing, here we: 1) prioritize organized social actors and, as a reflection of the transnational character of the oil palm value web, pay special attention to transnational activist and lobby groups, 'rooted in specific national contexts, but who engage in contentious political activities involving them in transnational networks of contacts and conflicts' (Tarrow 2005, 29); 2) focus on the transnational character of contention, understood by Tarrow as 'conflicts that link transnational activists to one another, to states, and to international 
institutions' (2005, 25); and 3) put forward an initial discussion on how major currents within those transnational politics impact the political economy of oil palm flexing.

Acknowledging there is a whole set of social actors working in more or less direct forms as campaigners and lobbyists for the oil palm complex, we set our attention here on two main currents of critical transnational activism according to their more-or-less reformist or counter-hegemonic political standpoint; namely those working to mitigate the negative socio-ecological impacts of the oil palm complex, and those leading oppositional struggles against $\mathrm{it}^{17}$. On the one hand, then, there are transnational organizations and advocacy coalitions who either do not see oil palm expansion as inherently problematic, or think that since it is unstoppable, it is better to bargain for better business deals for people on the ground and/or the environment. These organizations and coalitions engage with corporate actors and to a lesser extent with state actors. In doing so, they often draw on 'an old discourse of corporate social responsibility (hereafter CSR) [which] construes the corporation as a moral agent; like individuals, the enterprise is understood to have a social conscience (DeWinter, 2001)' (in O'Laughlin 2008, 947).

Arguably, social actors within this "middle-ground" positioning aim at making corporations more socially and ecologically responsible in two major ways. One way is by 'urging companies through analysis, outreach and participation in multistakeholder initiatives [...] to adopt and improve CSR instruments such as ethical principles, codes of conduct, disclosure, social audits and certification' (Utting 2008, 966). This is the case of (big international) development and conservation NGOs (BINGOs) operating at the core of the Roundtable for Sustainable Palm Oil (RSPO) and the Roundtable for Sustainable Biomaterials $\left(\mathrm{RSB}^{18}\right)$. Stakeholders at RSPO include these BINGOs, as well as banks, investors, consumer goods manufacturers, oil palm growers, processors, traders, and retailers (RSPO 2014). The RSB includes some technical government agencies ${ }^{19}$, and a few intergovernmental organizations such as UNEP, UNCTAD and IFPRI (RSB 2014). In both the RSPO and the RSB, the BINGOs play a significant role as 'sustainability gatekeepers' (Alonso-Fradejas 2015). That is, they negotiate with corporations over the social and ecological standards ("principles \& criteria") that the latter should be willing to impose on themselves. A so-called independent certification body (usually a BINGO, a university or a consultancy firm) is hired by the concerned company to assess its performance against the particular set of agreed principles and criteria it must comply with to be granted the "sustainability seal" 20 . In spite of their private and voluntary nature, these certification schemes are becoming a sine qua none condition for oil palm growers and manufacturers to access some important markets and customers. For example, RSPO certification is required to qualify as suppliers of palm oil to the powerful transnational companies (mostly from the Global North and not from BRIC and MIC countries) involved in production, circulation and

\footnotetext{
17 This framing builds on Borras, Franco and Wang's (2013) discussion on competing political responses to landgrabbing.

18 Originally born as the "Roundtable on Sustainable Biofuels" it was renamed in 2013 to include all sorts of biofuels and biomaterials.

${ }^{19}$ From Australia, The Netherlands, USA, U.K, Kenya and Switzerland

${ }^{20}$ This is an example of how 'NGOs involved in verifying compliance with CSR standards can become clients of the corporations they are supposed to be monitoring' (O'Laughlin 2008, 950).
} 
retailing of consumer goods, including Unilever and Cargill, which committed to buying only RSPOCertified palm oil from 2015 onwards $^{21}$.

Another route taken to make corporations in the oil palm value web more responsible in socioecological terms is via 'rankings and ratings, where organizations assess company policy and performance' (Utting 2008: 966). A meaningful example is that of Oxfam International's (OI) "Behind the Brands" Campaign. OI developed a Scorecard to 'assesses the agricultural sourcing policies of the world's 10 largest food and beverage companies ${ }^{22}$, which are large buyers of palm oil and potentially of the new uses from oil palm's biomass. The scorecard covers seven issues: 1) Transparency; 2) Women farm workers and small-scale producers; 3) Workers on farms; 4) Farmers (small-scale) growing the commodities; 5) Land; 6) Water; and 7) Climate. All but the transparency issue are assessed through indicators grouped into four categories: 1) awareness, 2) knowledge, 3) commitments, and 4) supply chain management (Oxfam-Behind the Brands 2014). As of January 2015, OI had published seven scorecards, the first in February 2013 and the latest in October 2014. They have gathered more than seven hundred thousand online signatures and provoked a series of compliance responses from several of the targeted companies (Business \& Human Rights Resource Centre 2014). One of the key campaign messages to the public reads:

'You're more powerful than any of the Big Ten food companies. Without you, they won't stay big for long. Use Facebook and Twitter to nudge your favourite brands. Contact the CEO personally and tell them what needs to change. We'll be constantly updating the scorecard so you can see the impact you're having' (Oxfam 2014).

In sum, and as argued by Bridget O'Laughlin, in trying to make corporations responsible, regulation becomes 'principally a privatized domain with civil society groups directly negotiating with and monitoring corporations’ (2008, 948). O’Laughlin goes on to argue that,

'the fact that a corporation claims that a particular activity has been undertaken as a reflection of its ethical concerns is no guarantee that it is contributing either to the general public good or to the well-being of the poor. Similarly, there is no assurance that civil society organizations and development agencies that presume to promote corporate social responsibility actually do so, nor that the actions they demand really benefit the poor and the oppressed' $(2008,948)$.

This said, it is worth acknowledging that some of these advocacy and campaigning efforts have been able to bring about positive changes in the business practices of corporate players. Nonetheless, in contributing to the framing of oil palm as a socio-ecologically responsible crop, these transnational social organizations, networks and coalitions may further legitimate the multiple uses of oil palm, the flexing among them, and therefore the continued expansion of oil palm plantations. As O'Laughlin questions, 'how can corporate initiatives be both profitable and consistent with the interests of the poor?' (O’Laughlin 2008: 945).

\footnotetext{
${ }^{21}$ Colombian FEDEPALMA's President in XVII International Conference on Palm Oil in Colombia, September 26 2012.

${ }^{22}$ Nestle, PepsiCo, Unilever, Mondelez, Coca-Cola, Mars, Danone, Associated British Foods (ABF), General Mills, and Kellogg's (Oxfam-Behind the Brands 2014)
} 
On the other hand, there are also transnational social actors opposing the workings of the oil palm complex because they consider them competing and inherently incompatible with the transformative project they strive for. These organizations, and their networks, coalitions and movements, often engage more with state actors and to a lesser extent with corporations. If, and when they do engage with the private sector, they often seek to make corporations accountable in ways in which 'social contestation, critical research and campaigns pushing for legal reforms have assumed a higher profile' (Utting 2008, 966). This is the case of transnational organizations and movements of counter-hegemonic character, struggling for a transformative life project from agrarian, environmental, food, gender and/or labor justice perspectives (among others). Their advocacy and campaigning efforts around the oil palm value web are often focused on the issues of land grabbing; climate change and environmental degradation; women's, indigenous peoples', peasants', fisherfolks' and pastoralists' rights; and arguably to a lesser extent, on labor conditions and rights. Some of these campaigns have been relatively successful in their goals too. For example, they have been important in the case of the various regulations across Latin America on land ownership by foreigners, and on the amount of land one person or company can own. They are also working in the making of the 2012 FAO-CFS' Voluntary Guidelines on the Responsible Governance of Tenure of Land, Fisheries and Forests in the Context of National Food Security an instrument of international governance which could potentially enhanced rural working peoples' abilities to access, use and control land and other natural resources. Also, partly due to advocacy and campaigning efforts in the EU, The European Commission stated that 'the assessment of how to minimise indirect land-use change emissions made clear that first generation biofuels have a limited role in decarbonising the transport sector [and thus] food-based biofuels should not receive public support after 2020' (European Commission 2014, 6-7) ${ }^{23}$.

However, the claims and critiques of these oppositional campaigns have been often de-legitimised by state, corporate and other competing social actors through their strategic use of flex policy narratives. For instance, the agrarian justice type of campaigning against land grabbing by oil palm companies has been usually countered by three main narratives. First is by reframing hunger and the need to feed an increasing world population as a problem of food availability, rather than one of access and distribution ${ }^{24}$. From this Malthusian perspective, oil palm is then presented as the best possible answer since it produces 'more oil in less land', when compared to other major commercial oilseeds (Hunsberger and Alonso-Fradejas 2015). The second narrative elaborates on a narrow understanding of contemporary land-grabbing which denies the phenomenon when "people on the ground" are not physically dispossessed from their land, like in the case of oil palm contract-farming (World Bank 2007). The third narratives is to frame oil palm as a food crop to confront the agrarian, food and/or environmental justice movements "land for food, not for fuel"-type of campaigning against oil palm, which can be encapsulated in the case of the Guatemalan Oil Palm Growers Guild

\footnotetext{
${ }^{23}$ For a meaningful analysis of the transnational campaign against oil palm expansion and palm-oil based-biodiesel involving activists in Indonesia and the EU, see Pye (2010)

${ }^{24}$ Oil palm industry representatives from Colombia, Ecuador and Guatemala, in I Latin American Conference of Oil

Palm Growers, Guatemala, October 182013
} 
(GREPALMA) arguing they are main contributors to 'food sovereignty' (Hunsberger and AlonsoFradejas 2015).

In sum both of these broad and somehow ideal types of critical advocacy and campaigning efforts have had some success in dealing with particular issues associated with expanding oil palm plantations, or with some of its multiple uses (e.g. biodiesel). What, then, does oil palm flexing imply for the efforts to make corporate actors in the oil palm value web either responsible or accountable? We have further engaged with this question on the implications of enhanced oil palm flexing possibilities for critical advocacy and campaigning efforts in a working paper published by the Transnational Institute (Alonso-Fradejas et al. 2015). Nonetheless, a fresh strand of theoretical and empirical research is needed, to which comparative studies developed at multiple scales and places could be a good contribution. It is with the will to support and encourage such research efforts that we conclude with some issues for further discussion.

\section{Conclusions}

We see future research as focused in three interconnected themes: the first would highlight the global political economy and the changing place of agricultural commodities in it; the second is related to the relations shaping and being shaped by the oil palm value web; and the third relates to the obscurity of oil palm flexibility.

We have argued that the dynamics of oil palm flexing- why it is flexed, how, by whom and where are closely related to world historical political and economic conditions and, more specifically, the current convergence of multiple global crises. The flexibility of oil palm is emerging alongside the crop's material, technological and profitability bases. Among these three bases, the first is satisfied through the natural character of oil palm, while the following two bases are connected to the current accumulation imperative, the green economy paradigm and the contemporary dynamics in the world food and agro-commodities regime. While, the international politico-economic conjuncture plays a key role in why a flex-commodity is more valuable at certain times, the extent of its value and the processes which ascribe this value are also impacted by regional differences and local complexities. Further research is needed to understand how these multiple layers converge and shape the commodity's flexibility and the paths it takes in the value web.

We also discussed that the 'how' and 'why' of oil palm flexing is heavily influenced not only by technological innovation but also by a synthesis of social forces and relations within and around the oil palm value web. These dynamics impact the way flexing among oil palm's different uses is influenced and/or done by various powerful actors within the state, the private sector, and civil society. In order to better address the question of whether and how the flexing of oil palm occurs within its value web, the relations and interactions of producers, traders, consumers, policy makers and the civil society actors deserves deeper analysis. In engaging with this discussion, the questions of who benefits from the flexing of oil palm, how they benefit, and at what costs, can also be approached. 
Another important area of analysis is the 'hidden' nature of oil palm flexing. We are left with the question of why oil palm flexibility remains so convoluted, and what the role of certain actors is in maintaining this obscurity. For example, when looking at the ingredients on packages of products containing palm oil, dozens of aliases are printed rather than simply "palm oil". If one picks up a beauty product on the long list of ingredients there is only "glycerine"-a deviation of palm oil. Why is this? And how does this contribute to the perplexing manner in which palm oil is flexed? Consumers without specific knowledge of palm oil and how it is fractionated cannot see when they purchased a palm oil-based product. What does this tell us about flex commodities? And to bring it an even broader level of analysis, what does it tell us about the current biotechnological, industrial agricultural complex?

All these questions may provide fresh empirical data on the possible impacts on different actors connected to the oil palm value web. One question that requires attention is whether, to what extent and in what ways, the strengthened flexibility of oil palm may shape trajectories of agrarian change. That is, how does increasing demand for oil palm's multiple products drive oil palm acreage expansion? How would the further expansion of oil palm change land (and water) use, access and control relations in the production sites? What implications could there possibly be on peasants, small-scale outgrowers, rural workers and on the environment? And even further, how can any concerned actor address the possible implications of, for example, palm oil flexing, if one cannot trace the way it is flexed because of its obscured value web? This connects to a question posed by Borras et al., 'How does one regulate palm oil, which has multiple and flexible uses? Should it be a concern for the food, fuel or industrial sector?' $(2014,4)$. On top of this, how can negatively impacted social groups address the actors and stages involved in the flexing of oil palm, considering its entangled value web?

Clearly, with the growing interest from financialized capital in oil palm's multiple uses, and with expensive bio-refineries coming into play, it is likely that the highly concentrated global value web of oil palm will become even more so. Corporations have increasingly more leverage within the global oil palm value web and, as the story often goes, this may lead to further co-option and appropriation of state actors and large NGOs within the narrative of economic development, responsibility, and sustainability.

\section{Acknowledgements}

This contribution is a result of the international workshop: "Problematizing and researching 'flex crops \& commodities': Reframing issues, rethinking actions". The workshop was co-organized by the Transnational Institute (TNI) and the Institute of Social Studies (ISS) on 23 January 2014, at the ISS, in The Hague. The authors are most grateful to TNI for funding such a workshop, as well as to the two anonymous reviewers, Jun Borras and Jennifer Franco for their meaningful comments on earlier versions. Any remaining errors are our own. 


\section{Short note on the contributors}

Alberto Alonso-Fradejas is a PhD Candidate at the International Institute of Social Studies (ISS) in The Netherlands, Research Associate of the Transnational Institute (TNI), and Fellow of the Guatemalan Institute of Agrarian and Rural Studies (IDEAR). Email: fradejas@iss.nl

Juan Liu is an Assistant Professor at College of Humanities and Social Development, Northwest A\&F University, China, and Post-doctoral Researcher at The International Institute of Social Studies (ISS), The Hague. She holds a PhD in Development Studies. Her research interests include internal migration and social policies, rural politics, land politics, and political economy of agriculture, environment and food. Email: juanlcau@gmail.com

Tania Salerno is a $\mathrm{PhD}$ candidate in the Anthropology and Sociology Department, University of Amsterdam. She is part of the research programme, '(Trans)national Land Investments in Indonesia and the Philippines: Contested Control of Farmland and Cash Crops', funded by NWO-WOTRO. Her research interests include agrarian development, land, financialized corporate agriculture and the global food system. Email: T.N.Salerno@uva.nl

Yunan $X u$ is a $\mathrm{PhD}$ Candidate at the International Institute of Social Studies (ISS) in The Netherlands, funded by the China Scholarship Council (CSC). Her research interests include industrial tree plantations, land, agrarian development, rural capitalism and food safety. Email: yunan@iss.nl

Corresponding author: Dr. Juan Liu (juanlcau@gmail.com)

\section{References}

Alonso-Fradejas, A. 2015, 'Anything but a story foretold: Multiple politics of resistance to the agrarian extractivist project in Guatemala', Journal of Peasant Studies.

Alonso-Fradejas, A.; J. Liu; T. Salerno; and Y. Xu 2015, 'The political economy of oil palm as a flex crop and its implications for transnational advocacy and campaigning: A preliminary discussion', Think Piece Series on Flex Crops \& Commodities No. 5, Amsterdam: Transnational Institute (TNI). In http://www.tni.org/category/series/think-piece-series-flex-crops-commodities

Be-Basic Foundation 2014, accessed on November 25 2014, http://www.be-basic.org/newscenter/news/oil-palm-biomass-center-industry-and-academia-join-forces-to-benefit-economy-andclimate.html

Bernstein, H. 2006, 'From Transition to Globalization: Agrarian Questions of Capital and Labour', International Conference on Land, Poverty, Social Justice and Development, 9-14 January 2006, Institute of Social Studies pp.1-22.

Borras, S.M., J.C. Franco, R. Isakson., L. Levidow, and P. Vervest, 2014, 'Towards understanding the politics of flex crops and commodities: Implications for research and policy advocacy', Think Piece Series on Flex Crops \& Commodities No.1, Amsterdam, Transnational Institute (TNI)

Borras , S.M., \& Franco, J.C. 2010,'From Threat to Opportunity-Problems with the Idea of a Code of Conduct for Land-Grabbing'. Yale Human Rights and Development Law Journal, 13(2): 507-23 
Borras, S.M. \& Franco J.C. 2013, 'Global Land Grabbing and Political Reactions 'From Below', Third World Quarterly, 34(9): 1723-1747

Borras, S.M., J.C. Franco, \& C. Wang 2013, 'The Challenge of Global Governance of Land Grabbing: Changing International Agricultural Context and Competing Political Views and Strategies', Globalizations Journal, 10(1): 161-179.

Business \& Human Rights Resource Centre 2014, accessed on January 8 2015, http://business-humanrights.org/en/natural-resources/allegations-of-abuse-company-responses-nonresponses/company-responses-to-oxfams-campaign-behind-the-brands-food-justice-and-the-big-10-foodand-beverage

Cargill 2011, 'Cargill begins offering certified sustainable palm oil to North American food manufacturers'. Retrieved on June 5 2014, from Cargill Corporate Website:

http://www.cargill.com/news/releases/2011/NA3046201.jsp

Cargill 2013, 'Cargill’s journey on palm oil' pp1-18. Cincinnati, OH.

Central America Link, December 26 2013, accessed on January 17 2014,

http://www.centralamericalink.com/es/Noticias/Guatemala duplica ventas de alimentos a Europa/

Corley, R. Hereward V., and P. B. H. Tinker 2003, The oil palm. Oxford: Blackwell,.

European Commission 2014, 'A policy framework for climate and energy in the period from 2020 to 2030', $\operatorname{COM}(2014)$ 15, Brussels.

FAOSTAT, accessed on Nov 2014, http://faostat3.fao.org/download/Q/QC/E

Fine, B.2012, 'La Financiarisation en Perspective', Actuel Marx 51: 73-85.

Fairhead, J., Leach, M., \& Scoones, I. 2012,'Green Grabbing: a new appropriation of nature?’ Journal of Peasant Studies, 39(2): 237-261.

Franco, J., Levidow, L., Fig, D., Goldfarb, L., Hönicke, M., \& Luisa Mendonça, M. 2010, 'Assumptions in the European Union biofuels policy: frictions with experiences in Germany, Brazil and Mozambique'. Journal of Peasant Studies, 37(4): 661-698.

Fox, J. 1993, The politics of food in Mexico: State power and social mobilization. Ithaca: Cornell University Press.

Friedmann, H. and P. McMichael, 1989, 'Agriculture and the State System: The Rise and Decline of National Agricultures, 1870 to the Present', Sociologia Ruralis 29(2): 93-117.

GACC Announcement No.74, 2013 on Oil-Product Import Consumption Tax, accessed on May 92014 , http://www.mofcom.gov.cn/aarticle/b/g/201103/20110307429707.html,

Goodman, D., B. Sorj, and J. Wilkinson 1987, From Farming to Biotechnology. A theory of Agro-industrial Development. Oxford and New York: Basil Blackwell

Harvey, D. 2003, The New Imperialism. New York: Oxford University Press. 
Hassan, M., and Y. Shirai. 2013. Palm Biorefinery for Sustainable Bioenergy, Biofuels and Biomaterials. 10th Biomass-Asia Workshop: Biomass Refinery to Community and Industrial Applications. Retrieved on July 7 2014 from:

http://www.biomass-asia-workshop.jp/biomassws/10workshop/download-file_10th_biomass-asiaworkshop/6 AUG 13/10.\%20Prof.Dr.Mohd\%20Ali $\% 20$ Hassan, $\% 20 U P M, \% 20 N E F \% 20$ Session.pdf

Hunsberger, C., and Alonso-Fradejas, A. 2015, 'The discursive flexibility of 'flex crops': comparing oil palm and jatropha', Journal of Peasant Studies.

ICEX 2013, accessed on December 16 2013, http://www.oficinascomerciales.es/icex/cda/controller/pageOfecomes/0,5310,5280449 52829575284940 $4697703 \mathrm{HN}, 00 . \mathrm{html}$

Isakson, R. 2014, 'Food and finance: the financial transformation of agro-food supply chains', Journal of Peasant Studies, 41(5): 754-782

La Tribuna, March 26 2013, accessed on November 19 2013, http://www.latribuna.hn/2013/03/26/malasiadestinara-100-millones-para-palmeros/

Loh, S. K., and Y. M. Choo. 2013. Prospect, Challenges and Opportunities on Biofuels in Malaysia. In Advances in Biofuels, ed. R. Pogaku and R. Hj Sarbatly, 3-14. US: Springer.

Margulis, M. E., McKeon, N., \& Borras, S. M. 2013, 'Land grabbing and global governance: critical perspectives', Globalizations, 10(1): 1-23.

McMichael, P. 2012, 'The land grab and corporate food regime restructuring'. Journal of Peasant Studies, 39 (34): 681-701.

Nalepa, R. A., \& Bauer, D. M. 2012, 'Marginal lands: the role of remote sensing in constructing landscapes for agrofuel development', Journal of Peasant Studies, 39(2): 403-422.

$\mathrm{Ng}$, Esther Jan 22 2014, 'China's biodiesel imports fall in weeks after imposition of blended fuel tax, accessed on January 24, 2014 from

http://www.platts.com/latest-news/agriculture/singapore/chinas-biodiesel-imports-fall-in-weeks-after$\underline{27855021}$

Oilseeds: World Markets and Trade 2006, accessed on November 25 2014, http://usda.mannlib.cornell.edu/usda/fas/oilseed-trade//2000s/2006/oilseed-trade-12-01-2006.pdf

Oilseeds: World Markets and Trade 2014, accessed on November 25 2014, http://apps.fas.usda.gov/psdonline/circulars/oilseeds.pdf

O'Laughlin, B. 2008, 'Governing capital? Corporate social responsibility and the limits of regulation’, Development and Change, 39(6): 945-957.

Oxfam 2014, accessed on January 8 2015, http://www.oxfam.org/en/campaigns/behind-brands

Oxfam-Behind the Brands 2014, accessed on January 10 2015, http://www.behindthebrands.org/en/about

Pye, O. 2010, 'The biofuel connection-transnational activism and the palm oil boom', Journal of Peasant Studies, 37(4): 851-874. 
Proceso, August 20 3013, accessed on November 19 2013, http://www.proceso.hn/2013/08/20/Econom\%C3\%ADa/Honduras.contar.C/73687.html

Reuters 2013, Tax incentives boost Chinese biodiesel imports, replace diesel, www.reutersreprints.com accessed on October 182013

Roundtable on Sustainable Biofuels (RSB), accessed on December 17 2014, http://rsb.org/about/organization/member-list/

Roundtable on Sustainable Palm Oil (RSPO), accessed on December 172014 http://www.rspo.org/members/all

Sachs, J. 2015, '2015 will be the year brands take a public stand on social issues', January 2,. The Guardian, accessed on January 4 2015, http://www.theguardian.com/sustainable-business/2015/jan/02/2015-socialjustice-race-equality-rights-climate-business-marketing

Sayer, J., Ghazoul, J., Nelson, P., \& Klintuni Boedhihartono, A. 2012, Oil palm expansion transforms tropical landscapes and livelihoods. Global Food Security, 1(2): 114-119.

Sonne, P. 2012, 'Unilever Takes Palm Oil in Hand', The Wall Street Journal. Asian Business News.

Tarrow, S.G. 2005, The New Transnational Activism. (Second edn.) Cambridge: Cambridge University Press.

Tarrow, S.G. 1998, Power in Movement: Social Movements and Contentious Politics. (Second edn.) Cambridge: Cambridge University Press.

The Star, March 21 2012, accessed on November 25 2014, http://biz.thestar.com.my/news/story.asp?file $=/ 2012 / 3 / 21 /$ business $/ 10954510 \& s e c=$ business

TU-Delft, November 21 2011, accessed on November 25 2014, http://www.tudelft.nl/en/current/latestnews/article/detail/oil-palm-biomass-center-opgericht-in-maleisie/

UNEP 2011, Towards a Green Economy: Pathways to Sustainable Development and Poverty Eradication, retrieved November 19, 2014, from www.unep.org/greeneconomy

Unilever2013a, 'Unilever accelerates market transformation for sustainable palm oil' The Guardian, http://www.theguardian.com/sustainable-business/unilever-market-transformation-sustainable-palm-oil retrieved on October 192014

Unilever 2013b, Unilever sustainable living plan 2013 http://www.unilever.com/images/slp UnileverSustainable-Living-Plan-2013 tcm13-388693.pdf retrieved on October 192014

USDA 2006, Oilseeds: World Markets and Trade, accessed on May 122014

http://usda.mannlib.cornell.edu/usda/fas/oilseed-trade/2000s/2006/oilseed-trade-12-01-2006.pdf

USDA 2013, PRC Biofuel Annual 2013, accessed on January 242013

http://gain.fas.usda.gov/Recent\%20GAIN\%20Publications/Biofuels $\% 20$ Annual Beijing China $\% 20$ \%20Peoples $\% 20$ Republic $\% 20$ of 9-9-2013.pdf

USDA-FAS 2014

http://apps.fas.usda.gov/psdonline/psdReport.aspx?hidReportRetrievalName=Table $+11 \% 3 \mathrm{a}+\mathrm{Palm}+\mathrm{Oil} \% 3$ $\underline{\text { a } \text { World }+ \text { Supply }+ \text { and }+ \text { Distribution\&hidReportRetrievalID }=710 \text { \&hidReportRetrievalTemplateID }=8}$ 
USDA 2014, Oilseeds: World Markets and Trade, accessed on May 122014

http://apps.fas.usda.gov/psdonline/circulars/oilseeds.pdf

Utting, P. 2008, 'The struggle for corporate accountability', Development and Change, 39(6): 959-975.

Virchow, D., M. Denich, A. Kuhn, and T. Beuchelt 2014, The Biomass-based Value Web as a Novel Perspective on the Increasingly Complex African Agro-food Sector. Tropentag, September 17-19.

White, B., S.M. Borras, R. Hall, I. Scoones, and W. Wolford 2012, 'The New Enclosures: Critical Perspectives on Corporate Land Deals', Journal of Peasant Studies 39(3-4): 619-647.

Wilmar 2013, Wilmar International Limited Annual Report 2013.

World Bank 2007, World Development Report 2008: Agriculture for Development. Washington DC: The World Bank.

ZSL Indonesia 2012, Sustainable Palm Oil Platform. Retrieved January 8, 2014, from

http://www.sustainablepalmoil.org/investors-traders/traders/ 